\title{
Microbiological Pollution Level and Seasonal Variations in Physicochemical Parameters of the River Buriganga, Dhaka
}

\author{
Md. Abdul Karim", Rehena Nasrin Happy ${ }^{1}$, Md. Saifur Rasul ${ }^{2}$ and Sirajul Hoque ${ }^{3}$ \\ ${ }^{1}$ Deaprtmrnt of Botany, University of Dhaka, ${ }^{2}$ Ambee Pharmacauticals, ${ }^{3}$ Department of Soil, Water and Environment, University of Dhaka.
}

\begin{abstract}
The Buriganga is one of the highly polluted rivers in Bangladesh. Most of the industries and factories of Dhaka are situated on the banks of the river Buriganga or very close to the river system. Substantial part of urban sewage of the Dhaka city is also disposed in the river Buriganga. The study was conducted to determine the pollution level of water of river Buriganga. Field investigation was started from May 2010 and sample collection was conducted in different seasons up to June 2011. Various water quality parameters such as pH, DO, BOD, COD, TDS, Conductivity, Alkalinity, $\mathrm{NO}_{2}^{-}-\mathrm{N}, \mathrm{NO}_{3}^{-}-\mathrm{N}, \mathrm{NH}^{+}-\mathrm{N}$ and $\mathrm{PO}_{4}^{-}$, were determined for water of each sampling points to monitor the level of these parameters where it exceeds or remain within the permissible limit. DO concentration of water of river Buriganga was very low ranging between 0.04 and $2.25 \mathrm{mg} / \mathrm{l}$. The aerobic heterotrophic bacterial count ranged between $1.0 \times 10^{7}$ and $2.0 \times 10^{8} \mathrm{cfu} / 100 \mathrm{ml}$. The highest count of enteric bacteria was noticed during the autumn that was $2.0 \times 10^{5} \mathrm{cfu} / 100 \mathrm{ml}$. BOD and COD values along with the presence of different species of bacteria clearly indicated that the water of the river Buriganga is highly polluted with the organic, chemical and bacterial pollutants.
\end{abstract}

Key words: Bacteria, Physicochemical parameters, Pollution level, Buriganga river

\section{Introduction}

The maintenance of water quality means that natural waters cannot be overloaded with organic or inorganic nutrients or with toxic, noxious, or esthetically unacceptable substances. They should not become vehicles of disease transmission from fecal contamination nor should their oxygenation, temperature, salinity, turbidity, or $\mathrm{pH}$ be altered significantly ${ }^{1}$.

Pollution can be caused by wide variety of inorganic and organic compounds and microorganisms often play a major role in determining the extent of this pollution ${ }^{2}$. Organic pollution occurs when organic compounds such as proteins, carbohydrates and fats which originate from domestic sewage, urban run-off and industrial effluent are released into the water bodies. They act as substrates for microorganisms ${ }^{3}$. The high concentration of heterotrophic bacteria increases the chance of the incidence of opportunistic pathogens of nonfaecal origin that can cause illness in the vulnerable groups of people $e^{4}$. The presence of faecal coliform is considered as presumptive evidence of faecal contamination ${ }^{5}$.

The river Buriganga is the country's main waterway for trading and ferry travel. For hundreds of years the river Buriganga has been continuously abused by unplanned urbanization and unplanned industrialization.

The river has become hygienically dead due to unabated dumping of untreated wastes including industrial, municipal, household, clinical and pathological wastes, oils and human excreta. Thus it is destroying not only its aquatic lives but also posing a serious threat to human health. Considering the above situation, the present work was undertaken to determine microbial pollution level and seasonal variations in physicochemical parameters of the river Buriganga.

\section{Materials and Methods}

Sampling sites and collection of water samples

The water samples were collected from two sites (Br-1 and $\mathrm{Br}-$ 2) of the River Buriganga, Dhaka, Bangladesh (Fig. 1) at morning (8-9 am). From each site, water samples were collected in plastic bottles previously and thoroughly washed with diluted $\mathrm{HCl}$ acid and later rinsed with de-ionized water followed by the sample water. Sample water was taken from a depth of approximately $30 \mathrm{~cm}$ below the surface level and carried back to the laboratory within an hour.

\section{Bacteriological analysis}

Nutrient agar (NA) medium was used for the enumeration and isolation of aerobic heterotrophic bacteria. MacConkey agar (Difco), SS agar (Diagnostic Pasteur) and Cetrimide agar media were used for the determination and isolation of enteric, pathogenic and related bacteria. The $\mathrm{pH}$ of the isolation media was adjusted to 6.8 (because most of the samples were within the range of 6.87.2) before sterilization. Three different techniques, viz. serial dilution $^{6}$, spread plate ${ }^{7}$ and membrane filtration technique ${ }^{8}$ were used for the enumeration and isolation of bacteria. Inoculated bacterial plates were incubated at $37^{\circ} \mathrm{C}$ for $24 \mathrm{~h}$.

Bacterial colony counting was made with the help of a Digital colony counter (OSK 10086, DC-3, Japan). Colonies were counted from responsive plates and expressed as cfu/100 ml and discrete bacterial colonies were isolated immediately after 
counting. For provisional identification of bacteria, important biochemical tests were carried out, viz. carbohydrate fermentation, catalase test, deep glucose agar test, tyrosine degradation, egg-yolk lecithinase test, casein hydrolysis, protease test, starch hydrolysis, Kligler's iron agar (KIA) test, levan test, methyl red test, nitrate reduction test, oxidase test, indole production, phenylalanine deaminase test, citrate utilization, utilization of propionate, urease production test and Voges Proskauer (VP) tests. Bergey's Manual for Systematic Bacteriology, Vol. $2^{9}$ was followed for the identification of Gram-positive aerobic heterotrophic bacterial isolates. On the other Manual for Laboratory Investigations of Acute Enteric Infections ${ }^{10}$ and Bergey's Manual of Systematic Bacteriology $\left(\right.$ Vol.1) ${ }^{11}$ were used for identification of enteric bacteria.

\section{Determination of physico-chemical properties}

Water temperature was measured at the time of sampling with the help of thermometer. The $\mathrm{pH}$ of water samples was measured in the laboratory by electronic pH meter (Jenway 3310, U.K.). The dissolved oxygen (DO) and biochemical oxygen demand (BOD) of the collected samples were obtained using digital DO meter (Jenway $970 \mathrm{DO}_{2}$, U.K.). Conductivity of the water samples was measured with the help of multi-range Hanna conductivity meter (MODEL-HI 9033). Total dissolved solids (TDS) of the samples were measured with the help of Hanna TDS meter (MODEL-HI 9034). The values were recorded in $\mathrm{mg} / \mathrm{l}$. Alkalinity of water was determined by Titration method. The unit of alkalinity was noted in meq/1 ${ }^{12}$. For chemical analysis, samples were filtered (Whatman No. 42, England) to eliminate suspended solid particles. Nitrite-nitrogen present in water was determined by modified Griess-Ilosvay method ${ }^{13,14}$. Nitrate-nitrogen was determined colorimetrically ${ }^{15}$. Soluble reactive phosphorus was determined by ascorbic acid blue color method $^{16}$. Chemical oxygen demand (COD) was determined by the method based on chemical oxidation of materials in the presence of catalyst ${ }^{17}$.

\section{Results}

The heterotrophic bacterial count of water samples has been presented in Table 1. During the rainy season, maximum number of bacterial count was observed both in BR-1 (Shyam bazar) and BR-2 (Ultinganj) and it was $2.0 \times 10^{8} \mathrm{cfu} / 100 \mathrm{ml}$, while minimum number was detected in BR-1 during autumn and it was $1.0 \times 10^{7} \mathrm{cfu} / 100 \mathrm{ml}$.

Enteric and related bacterial count on MacConkey agar, SS agar and Cetrimide agar media has been shown in Table.1. Enteric bacterial count on MacConkey agar ranged between 3.0×104 $\mathrm{cfu} / 100 \mathrm{ml}$ to and $2.0 \times 10^{5} \mathrm{cfu} / 100 \mathrm{ml}$ and the highest count was found in the sample of BR-1. Bacterial count on SS agar medium varied between $2.8 \times 10^{5} \mathrm{cfu} / 100 \mathrm{ml}$ to uncountable. During this study heterotrophic along with the enteric bacterial load ranged between $1.0 \times 10^{7}$ and $2.0 \times 10^{8} \mathrm{cfu} / 100 \mathrm{ml}$. The bacterial count on Cetrimide agar was ranged between 0.0 and $1.4 \times 10^{3} \mathrm{cfu} / 100 \mathrm{ml}$.

During this investigation, of the 110 isolates, 36 were randomly selected and purified for detailed study. Among these, 22 were Gram-positive and remaining 14 were Gram-negative. All the Gram-positive isolates were rod shaped, spore former and members of the genus Bacillus, while the rest three Gramnegative isolates belong to the genus Xanthomonas.

Enteric bacteria were Gram-negative, short rod and non-spore former. Out of 11 Gram-negative enteric bacterial isolates, 3 (27.3\%) isolates belonged to the genus Escherichia, 3 (27.3\%) isolates were Proteus morganii, and the remaining isolates were Escherichia coli-Alk. (9.1\%), Yersinia (9.1\%), Plesiomonas (9.1\%), Hafnia (9.1\%) and Alcaligenes (9.1\%) (Table 2). Physicochemical properties of the water of the river Buriganga are given in Table 3.

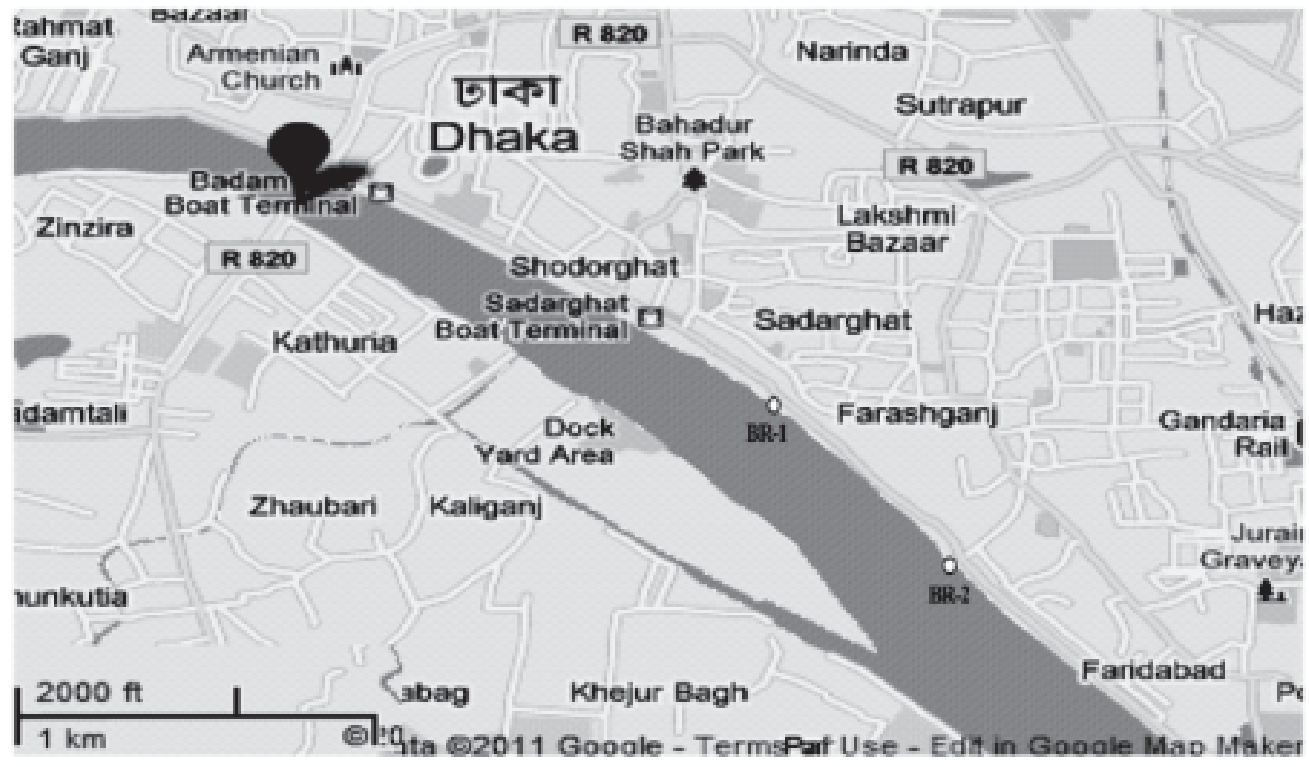

Figure 1. Map showing different sampling sites of the river Buriganga, Dhaka, Bangladesh (Br-1 = Shyam bazar and Br-2 = Ultinganj). 
Table 1. Bacterial count (cfu/100 ml) of water samples of the river Buriganga

\begin{tabular}{|c|c|c|c|c|c|}
\hline \multirow[t]{2}{*}{ Seasons } & \multirow{2}{*}{$\begin{array}{l}\text { Sampling } \\
\text { stations }\end{array}$} & \multirow{2}{*}{$\begin{array}{c}\text { Aerobic } \\
\text { heterotrophic } \\
\text { bacteria on Nutrient } \\
\text { agar }\end{array}$} & \multicolumn{2}{|c|}{ Enteric and related bacteria on } & \multirow{2}{*}{$\begin{array}{l}\text { Pathogenic } \\
\text { bacteria on } \\
\text { Cetrimide } \\
\text { agar }\end{array}$} \\
\hline & & & $\begin{array}{c}\text { MacConkey } \\
\text { agar }\end{array}$ & SS agar & \\
\hline \multirow[t]{2}{*}{ Summer } & BR-1 & $8.5 \times 10^{7}$ & $5.0 \times 10^{4}$ & ND & $3.0 \times 10^{2}$ \\
\hline & BR-2 & $5.0 \times 10^{7}$ & $1.2 \times 10^{5}$ & ND & $1.0 \times 10^{2}$ \\
\hline \multirow[t]{2}{*}{ Rainy } & BR-1 & $2.0 \times 10^{8}$ & $3.0 \times 10^{4}$ & $2.8 \times 10^{5}$ & - \\
\hline & BR-2 & $2.0 \times 10^{8}$ & $6.5 \times 10^{4}$ & $1.2 \times 10^{5}$ & - \\
\hline \multirow[t]{2}{*}{ Autumn } & BR-1 & $1.0 \times 10^{7}$ & $2.0 \times 10^{5}$ & Not countable & $1.4 \times 10^{3}$ \\
\hline & BR-2 & $3.0 \times 10^{7}$ & $5.0 \times 10^{4}$ & & $8.0 \times 10^{2}$ \\
\hline
\end{tabular}

Table 2. Provisional identification of the selected bacterial strains

\begin{tabular}{|c|c|c|c|}
\hline Isolate No & Provisional Name & Isolate No & Provisional Name \\
\hline BW-1 & Bacillus sp. & BW-30 & Bacillus sp. \\
\hline BW-2 & Xanthomonas sp. & BW-32 & Bacillus sp. \\
\hline BW-4 & Xanthomonas sp. & BW-35 & Bacillus sp. \\
\hline BW-6 & Bacillus sp. & BW-37 & Bacillus sp. \\
\hline BW-7 & Bacillus sp. & BW-38 & Bacillus sp. \\
\hline BW-8 & Bacillus sp. & BW-41 & Bacillus sp. \\
\hline BW-13 & Xanthomonas sp. & BW-44 & Bacillus sp. \\
\hline BW-14 & Bacillus sp. & $\mathrm{E}-2$ & Yersinia enterocolitica \\
\hline BW-15 & Bacillus sp. & E-4 & Proteus morganii \\
\hline BW-16 & Bacillus sp. & E-8 & Plesiomonas sp. \\
\hline BW-18 & Bacillus sp. & E-12 & Escherichia coli \\
\hline BW-19 & Bacillus sp. & E-14 & Escherichia coli \\
\hline BW-20 & Bacillus sp. & E-15 & Hafnia sp. \\
\hline BW-21 & Bacillus sp. & E-16 & Alcaligenes sp. \\
\hline BW-22 & Bacillus sp. & E-19 & Escherichia coli- Alk. \\
\hline BW-23 & Bacillus sp. & $E-20$ & Proteus morganii \\
\hline BW-24 & Bacillus sp. & E-23 & Proteus morganii \\
\hline BW-25 & Bacillus sp. & E-26 & Escherichia coli \\
\hline
\end{tabular}


Table 3. Physicochemical properties of the water samples of the river Buriganga

\begin{tabular}{|c|c|c|c|c|c|c|}
\hline \multirow[t]{2}{*}{ Sampling stations } & \multirow[t]{2}{*}{ Parameters } & \multicolumn{4}{|c|}{ Seasons } & \multirow[b]{2}{*}{ Winter } \\
\hline & & Summer & Rainy & Autumn & Late autumn & \\
\hline \multirow[t]{11}{*}{ BR - 1} & $\mathrm{pH}$ & 6.79 & 7.09 & 7.06 & 6.81 & 6.92 \\
\hline & DO (mg/l) & 0.78 & 2.02 & 1.34 & 2.25 & 0.08 \\
\hline & BOD (mg/l) & 0.58 & 0.78 & 0.76 & 0.60 & 0.08 \\
\hline & COD (mg/l) & ND & 55.40 & 47.05 & 46.00 & ND \\
\hline & TDS (mg/l) & 145.30 & 77.69 & 75.49 & 79.67 & 582.67 \\
\hline & Conductivity $(\mu \mathrm{s} / \mathrm{l})$ & 300.00 & 416.99 & 443.34 & 511.00 & 303.00 \\
\hline & Alkalinity (meq/l) & 2.20 & 6.85 & 2.03 & 1.20 & 2.45 \\
\hline & $\mathrm{PO}_{4}^{-}(\mathrm{mg} / \mathrm{l})$ & 0.08 & ND & 0.06 & 0.11 & 0.25 \\
\hline & $\mathrm{NO}_{2}-\mathrm{N}(\mathrm{mg} / \mathrm{l})$ & 0.01 & ND & 0.01 & 0.01 & 0.02 \\
\hline & $\mathrm{NO}_{3}^{-}-\mathrm{N}(\mathrm{mg} / \mathrm{l})$ & Trace & ND & Trace & 2.00 & 1.00 \\
\hline & $\mathrm{NH}_{4}^{+}-\mathrm{N}(\mathrm{mg} / \mathrm{l})$ & 2.95 & ND & 4.90 & 6.40 & 3.00 \\
\hline \multirow[t]{11}{*}{ BR - 2} & $\mathrm{pH}^{4}$ & 6.61 & 7.08 & 7.02 & 6.93 & 7.14 \\
\hline & DO (mg/l) & 0.73 & 1.79 & 1.19 & 2.03 & 0.04 \\
\hline & BOD (mg/l) & 0.60 & 1.48 & 0.595 & 1.52 & 0.04 \\
\hline & COD (mg/l) & ND & 50.00 & 42.20 & 43.25 & ND \\
\hline & TDS (mg/l) & 144.7 & 80.34 & 78.65 & 87.00 & 538.83 \\
\hline & Conductivity ( $\mu \mathrm{s} / \mathrm{l})$ & 298.30 & 450.30 & 240.60 & 511.00 & 299.67 \\
\hline & Alkalinity (meq/l) & 2.15 & 6.70 & 1.55 & 1.10 & 1.90 \\
\hline & $\mathrm{PO}_{4}^{-}(\mathrm{mg} / \mathrm{l})$ & ND & ND & 0.055 & 0.09 & 0.18 \\
\hline & $\mathrm{NO}_{2}-\mathrm{N}(\mathrm{mg} / \mathrm{l})$ & ND & ND & 0.04 & 0.01 & 0.01 \\
\hline & $\mathrm{NO}_{3}^{-}-\mathrm{N}(\mathrm{mg} / \mathrm{l})$ & ND & ND & Trace & 4.00 & 2.00 \\
\hline & $\mathrm{NH}_{4}^{+}-\mathrm{N}(\mathrm{mg} / \mathrm{l})$ & ND & ND & 11.28 & 4.00 & 2.00 \\
\hline
\end{tabular}

\section{Discussion}

Heterotrophic bacterial load in the rainy season was found to be higher than the autumn. This might be due to wash out of the land surface to the river through rainwater. Shyam bazar area was highly polluted with enteric bacterial pollution. Interestingly the highest count of enteric bacteria was noticed during the autumn. The results demonstrated that the river Buriganga is considerably polluted with bacterial population. Almost similar results showing the load of heterotrophic and nitrifying bacteria in the river and sewage lagoon was reported ${ }^{18,19}$. Dynamic of aquatic micro flora are subjected to variations from year to year. The movement of water by wind, tide or currents accomplished some redistribution of the microbial flora ${ }^{20}$. Escherichia sp. and Proteus morganii was found to be the dominant group among the Gram-negative bacteria in the river. Bacterial strains isolated from fresh water bodies of Bangalore and the dominant genera were Bacillus, Pseudomonas, Enterobacter, Aeromanas, Flavobacterium, Corynobacterium etc. ${ }^{21}$. The coliform group of bacteria in general and $E$. coli in particular has found universal application as indicators of faecal contamination and has been employed as sewage pollution indicators ${ }^{22}$.

On the other hand the load of aerobic heterotrophic bacteria and the presence and abundance of Bacillus sp., Escherichia spp., Proteus morganii, Plesiomonas sp., Hafnia sp. and Alcaligenes sp. in the water clearly showed significant level of microbial pollution in the river.
The findings from the present study are nearly similar to another report showing lower $\mathrm{pH}$ and $\mathrm{DO}$ values during dry season in the surface water ${ }^{23}$. Concentration of DO in river water was very low for the survival of the aquatic lives. This low DO (0.04$2.25 \mathrm{mg} / \mathrm{l}$ ) level could result in the non-maintenance of conditions favorable to the gill-breathing aquatic organisms and increase the sensitivity of fish to chemicals ${ }^{24}$.

According to United State Public Health (USPH) standard, 5 $\mathrm{mg} / \mathrm{l}$ and $4 \mathrm{mg} / \mathrm{l}$ value of BOD and COD, respectively indicate the quality for domestic and drinking water ${ }^{17}$. The normal range of BOD for good water quality is 5-6 mg/l and COD is 6-10 $\mathrm{mg} / \mathrm{l}^{25}$. On the basis of BOD (0.04-1.52 mg/l) and COD (42.2$55.4 \mathrm{mg} / \mathrm{l}$ ) values, the river water was polluted with organic and chemical pollutants.

During the study period the TDS value ranged between 75.49 $\mathrm{mg} / \mathrm{l}$ to $582.67 \mathrm{mg} / \mathrm{l}$. The Bangladesh center for advanced studies reported that TDS of Sitalakhya river crossed the limit and it raised from 216 to $446 \mathrm{mg} / \mathrm{l}$ during 1980 to 1998 period $^{26}$. The TDS of the water of four rivers in Sundarban varied seasonally from 0.43 to $44.4 \mathrm{~g} / \mathrm{l}^{27}$. The present investigation well agrees with the previous findings ${ }^{26-27}$.

\section{Acknowledgement}

The authors gratefully acknowledge the support in part by a grant from the Biotechnology Research Centre, University of Dhaka, Dhaka - 1000, Bangladesh for the session 2009-2010. 


\section{References}

1. Atlas RM and Bartha R. 1998. Microbial Ecology, $4^{\text {th }}$ edn, pp 694. Addison Wesley Longman, Inc. California.

2. Higgins IJ and Burns RG. 1975. The Chemistry and Microbiology of Pollution, 8: pp 256 Academic Press, London.

3. Mason CF. 2002. Biology of fresh water pollution, $4^{\text {th }}$ edn, pp 1-387. Prentice-Hall, London.

4. Hunter PR. 1993. The microbiology of bottled natural mineral waters. $J$. Appl. Bacteriol. 74: 345-352.

5. Mara D. 1978. Sewage Treatment in Hot Climates, pp 168. John Wiley and sons, New York.

6. Clesceri LS, Greenberg AE and Eaton AD. 1998. Standard methods for the examination of water and wastewater, $20^{\text {th }}$ edn, pp 9-71. APHA, Washington DC, USA.

7. Sharp MS and Lyles ST. 1969. Laboratory instruction in biology of microorganisms, pp 23-25. Saint Louis the C V Mosley Company.

8. Atlas RM, Brown AE and Parks LC. 1995. Experimental Microbiology, pp 90. Mosby Year Book, Inc. USA.

9. Sneath PHA, Mair NS, Sharpe ME and JG Holt (Eds.). 1986. Bergey's manual of systematic bacteriology, $9^{\text {th }}$ edn, vol. 2, pp 1-1594. The Williams and Wilkins Co., Baltimore, USA.

10. WHO. 1987. Manual for laboratory investigations of acute enteric infections, pp. 106. Geneva.

11. Krieg NR and Holt JG (Eds.). 1994. Bergey's Manual of Systematic Bacteriology, vol 1, pp 1-964. The Williams and Wilkins Company, Baltimore, USA.

12. Mackereth FJH, Heron J and Talling JF. 1978. Water Analyses: Some revised methods for limnologists, pp 120. Freshwater Biol. Assoc. Sci. Publication.

13. Barnes H and Folkard AR. 1951. The determination of nitrites. Analyst (London). 76: 599-603.

14. Bremner JM. 1965. Nitrogen availability indexes. Agronomy. 9: 1324-45.
15. Joergensen RG and Brookes. 1990. Ninhydrin reactive nitrogen measurements of microbial biomass in $0.5 \mathrm{M} \mathrm{K}_{2} \mathrm{SO}_{4}$ soil extracts. Soil Biology and Biochemistry. 22: 1023-1027.

16. Murphy J and Riley JP. 1962. A modified single solution method for determination of phosphate in natural water. Anal. Chem. Acta. 27: 31-36.

17. De AK. 2000. Environmental chemistry, $4^{\text {th }}$ edn, pp 1-916. New Age International Limited Publishers, New Delhi.

18. Garnier J, Billen G and Servais P. 1992. Physiological characteristics and ecological role of small and large sized bacteria in a polluted river (Seine River, France). Arch Hydrobiol Ergebn Limnol. 37: 83-94.

19. Hasan MM, Ahmed MK, Hafiz F, Hussain AMI, Parveen S and Tinni SR. 2006. Load of Heterotrophic and Nitrifying Bacteria in the Sewage Lagoon and the River Buriganga. Bangladesh J. Microbiol. 23(2): 93-97.

20. Pelczar MR Jr, Chan ECS and Krieg NR. 1993. Microbiology: Concept and Applications, pp 1-896. McGraw-Hill Book Company, New York.

21. Varatraj P and Ayjapan S. 1989. Population and distribution of heterotrophic bacterial flora in freshwater bodies of Bangalore (India). Indian J. Environ. Health. 31(2): 162-170.

22. Godfree AF, Kay D and Wyer MD. 1997. Faecal streptococci as indicators of faecal contamination in water. J. Appl. Micribiol. Symp. 83: 110S-119S.

23. Das M, Ahmed MK, Islam MM, Akter MS, Islam MS and Mansur M. 2010. Heavy metal concentrations in industrial effluents (Tannery and Textile) and water of adjacent river. Terrestrial and Aquatic Environ. Toxicol. 4(1): 8-13.

24. DWAF, 1992. Analytical methods Manual, TR 151. Department of Water Affairs and Forestry, Pretoria, SA.

25. Huq SMI and Alam MD (Eds). 2005. A Handbook on Analyses of Soil, Plants, and Water, pp 1-246. BACER-DU, Dhaka, Bangladesh.

26. BCAS. 2000. Pollution Study, Management of Aquatic Ecosystem through Community Husbandry (MACH), Dhaka, Bangladesh.

27. Alam AMS, Islam MA, Rahman MA, Alam MN, Siddique M and Matin MA. 2003. Comparative study of the toxic metals and nonmetal status in the major river system of Bangladesh. Dhaka University J. Sci. 51(2): 201- 208. 